\title{
Pelatihan Pemasaran Digital untuk Meningkatkan Keterampilan Pelaku UMKM di Desa Srumbung Magelang
}

\author{
Digital Marketing Training to Improve the Skills of MSMEs Players in Srumbung Village, \\ Magelang
}

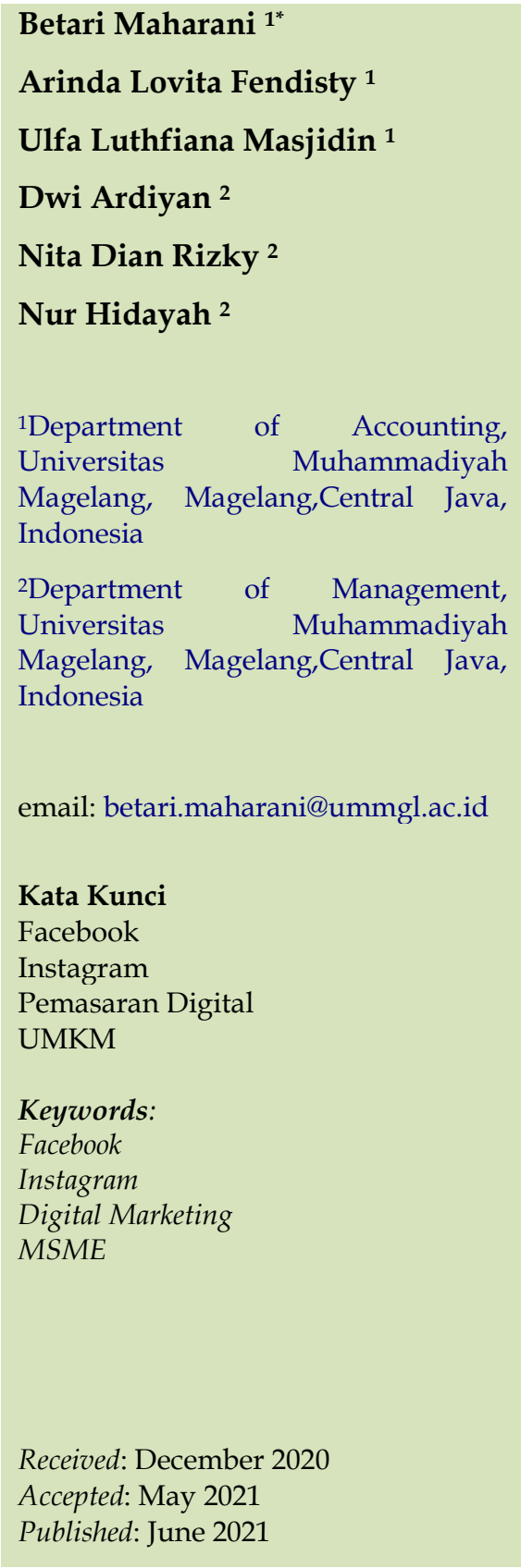

\begin{abstract}
Abstrak
Ada 26 Usaha Mikro Kecil dan Menengah (UMKM) di Desa Srumbung yang terdaftar di kantor desa. Namun tidak semua UMKM berjalan dengan baik. Sebagian besar pelaku UMKM memiliki pengetahuan dan keterampilan yang terbatas dalam menggunakan teknologi informasi. Sedangkan keberadaan teknologi informasi bagi pelaku UMKM sangat penting, terutama sejak munculnya Covid-19 dan penerapan kebijakan Pembatasan Sosial Berskala Besar (PSBB). Keberadaan UMKM akan terhambat atau terpuruk jika tidak memanfaatkan teknologi dalam kegiatan usahanya. Oleh karena itu, tujuan pengabdian masyarakat ini adalah untuk meningkatkan pengetahuan dan keterampilan para pelaku UMKM dalam memanfaatkan Facebook dan Instagram sebagai sarana pemasaran online. Pengabdian masyarakat dilaksanakan pada tanggal 20 Oktober 2020 hingga 5 November 2020. Pesertanya adalah 4 UMKM, terdiri dari UMKM Jenang \& Krasikan, Keripik Pegagang, Sagon Kering dan Manisan Salak. Metode yang digunakan adalah edukasi (sosialisasi) tentang pemasaran online dan pelatihan pengoperasian dan manajemen media sosial Facebook dan Instagram. Hasil dari pengabdian masyarakat ini adalah meningkatnya pengetahuan dan keterampilan peserta dalam mengoperasikan dan mengelola Facebook dan Instagram sebagai media pemasaran digital. Selain itu, masing-masing UMKM juga telah memiliki akun bisnis di media sosial. Jaringan dengan pemasok bahan baku dan pelanggan juga mulai terbangun melalui akun media sosial yang dibuat.
\end{abstract}

\begin{abstract}
There are 26 Micro, Small, and Medium Enterprises (MSMEs) in Srumbung Village registered at the village office. However, not all MSMEs run well. Most of the MSMEs players have limited knowledge and skills in using information technology. Meanwhile, information technology for MSMEs players is critical, especially since the emergence of the Covid-19 and the implementation of the PSBB (Pembatasan Sosial Berskala Besar) policy. The existence of MSMEs will be hampered or slumped if they do not utilize technology in their business. Therefore, this society's dedication aims to improve the knowledge and skills of MSMEs players on utilizing Facebook and Instagram as online marketing tools. Society dedication was conducted from October 20, 2020, to November 5, 2020. The participants are 4 MSMEs, consist of Jenang \& Krasikan, Keripik Pegagang, Sagon Kering dan Manisan Salak. The method used is education (socialization) about online marketing and operating and management training of Facebook and Instagram. This society's dedication is the increase of knowledge and skills of participants in operating and managing social media Facebook and Instagram as digital marketing media.
\end{abstract} Palangkaraya. This is Open Access article under the CC-BY-SA License (http://creativecommons.org/licenses/by-sa/4.0/). DOI: https://doi.org/10.33084/pengabdianmu.v6i4.1926 


\section{PENDAHULUAN}

Perkembangan Usaha Mikro, Kecil dan Menengah (UMKM) berpengaruh terhadap pendapatan nasional sektor UMKM di Indonesia (Hamza \& Agustien, 2019). Berbagai UMKM tersebut memegang peranan penting dalam perkembangan perekonomian Indonesia, baik ditinjau dari segi jumlah usaha, segi penciptaan lapangan kerja, maupun dari segi pertumbuhan ekonomi nasional yang diukur dengan produk domestik (Ananda \& Susilowati, 2017). Terutama, UMKM berperan dalam perkembangan distribusi hasil. Sejauh ini, UMKM telah berkontribusi sebanyak 57,6\% Produk Domestik Bruto (PBD) dan mempunyai tingkat penyerapan tenaga kerja sekitar $97 \%$ dari seluruh tenaga kerja nasional (Lembaga Pengembangan Perbankan Indonesia Bank Indonesia, 2015). UMKM juga telah terbukti tidak terpengaruh oleh krisis. Ketika krisis yang melanda pada periode 19971998, hanya UMKM yang dapat kuat bertahan.

Desa Srumbung terletak di Kecamatan Srumbung, Kabupaten Magelang, Provinsi Jawa Tengah. Terdapat empat belas dusun yakni Ngaglik, Cawakan, Wates, Ngelorejo, Jamblangan, Soropadan Kidul, Soropadan Lor, Srumbung Krajan, Srumbung Kauman, Pondok, Cabe Kidul, Cabe Lor, Ngepos, Dowakan. Mayoritas penduduk Desa Srumbung memiliki mata pencaharian sebagai petani dan sebagian lainnya bermata pencaharian sebagai guru, pedagang, penambang pasir serta buruh.

Terdapat banyak UMKM yang tersebar di setiap dusun di desa Srumbung. Kebanyakan usaha bergerak pada usaha makanan seperti jenang dan krasikan, aneka kripik, gula kelapa, slondok, sagon kering, tempe dan manisan salak. Terdapat 26 UMKM yang terdaftar di kantor kelurahan desa Srumbung pada tahun 2020, namun sayangnya dari 26 UMKM yang terdaftar tidak semua UMKM berjalan dengan lancar. Berdasarkan hasil observasi, ditemukan beberapa permasalahan yang dihadapi oleh pelaku UMKM diantaranya terkait aspek permodalan, sumberdaya manusia dan minimnya jaringan pengembangan bisnis, serta tidak adanya branding pada usaha dan produknya. Permasalahan ini merupakan bentuk permasalahan internal yang dialami oleh pelaku UMKM di Desa Srumbung.

Permasalahan yang berasal dari eksternal UMKM adalah terkait dengan kompetitor dan infrastruktur dalam memasarkan produknya. Selain itu, adanya kondisi pandemi Covid-19 saat ini, membatasi mobilisasi masyarakat dan barang yang berdampak pada terbatasnya kegiatan operasional UMKM dan berkurangnya konsumen yang berbelanja secara langsung (Pakpahan, 2020). Berdasarkan permasalahan tersebut, maka digitalisasi pada mekanisme transaksi bisnis melalui pemanfaatan media sosial menjadi alternatif solusi yang dapat dilakukan. Melalui media sosial, para pelaku usaha dapat memasarkan produknya dalam kemasan yang lebih menarik dan menjangkau jaringan masyarakat yang lebih luas, sehingga kesulitan pemasaran dan potensi kehilangan pasar dapat teratasi. Akan tetapi, kenyataan saat ini menunjukkan bahwa masih banyak unit usaha dengan skala mikro, kecil dan menengah yang belum dapat memanfaatkan secara maksimal media sosial dalam bisnis mereka (Cesaroni \& Consoli, 2015). Oleh karena itu, edukasi bisnis digital sangat diperlukan untuk membantu para pelaku UMKM.

Selama ini, produk UMKM di Desa Srumbung dipasarkan secara langsung kepada konsumen. Namun, dengan adanya kondisi saat ini, metode pemasaran langsung kurang dianjurkan oleh pemerintah, karena dapat berpotensi menyebarkan virus Covid-19 (Bakhri \& Futiah, 2020). Penggunaan media sosial sebagai alat pemasaran sangat dibutuhkan oleh para pelaku usaha untuk mengatasi penurunan jumlah pelanggan dan omset penjualan UMKM (Raharja \& Natari, 2021). Akan 
tetapi, para pelaku UMKM di Desa Srumbung memiliki keterbatasan pengetahuan dan keterampilan dalam menggunakan media sosial sebagai alat pemasaran produknya. Untuk mengatasi permasalahan tersebut, maka memberikan edukasi bisnis digital melalui pemanfaatan media sosial sebagai alat pemasaran sangat penting untuk dilakukan.

Berdasarkan permasalahan dan alternatif solusi yang dapat dilakukan, maka tim kegiatan pengabdian memberikan pengarahan, pelatihan dan pendampingan kepada pelaku UMKM Desa Srumbung terkait dengan penggunaan media sosial untuk pemasaran produk. Tujuannya adalah untuk meningkatkan pemahaman dan keterampilan pelaku UMKM dalam mengoperasikan dan mengelola media sosial sebagai sarana pemasaran, sehingga dapat mempermudah kegiatan usaha khususnya dalam hal transaksi dan peningkatan jumlah konsumen.

\section{METODOLOGI}

Kegiatan pengabdian masyarakat di Desa Srumbung dilakukan melalui beberapa tahapan diantaranya adalah penyusunan proposal; survei; pengurusan kontrak kerjasama mitra pengabdian; persiapan alat, bahan dan materi pengabdian; dan pelaksanaan kegiatan pengabdian. Pada tahap pelaksanaan kegiatan pengabdian, tim pengabdian memberikan sosialisasi dan pelatihan. Kegiatan sosialisasi dilaksanakan pada 25 Oktober 2020 yang diisi dengan pemaparan materi tentang pentingnya pemasaran digital dan pemanfaatan media sosial sebagai media promosi pemasaran. Kegiatan pelatihan dilaksanakan pada 5 November 2020, yang diisi dengan pengenalan beberapa media sosial, pelatihan pengoperasian dan pengelolaan media sosial sebagai sarana pemasaran. Adapaun peserta sosialisasi dan pelatihan sebanyak 4 UMKM yang terdiri dari
UMKM Jenang \& Crasikan, UMKM Keripik Pegagang, UMKM Sagon Kering dan UMKM Manisan Salak

Adapun langkah pelaksanaan kegiatan adalah sebagai berikut:

1. Sosialisasi dan koordinasi dengan mitra terkait jadwal pelaksanaan kegiatan pelatihan pemasaran digital serta lokasi kegiatan. Pada tahap koordinasi awal ini dilakukan penentuan hari dan jam yang tepat untuk memberikan materi pelatihan dengan tujuan agar penyampaian materi dapat dilakukan secara maksimal dan tepat sasaran.

2. Persiapan penyuluhan dan pelatihan. Pada tahap ini, yang disiapkan berupa materi pengenalan program kegiatan serta akun email yang digunakan untuk membuat akun media sosial UMKM.

3. Pelaksanaan pelatihan pemasaran digital. Pada tahap ini dilakukan kegiatan pemaparan materi (sosialisasi) tentang pentingnya memanfaatkan media digital sebagai media pemasaran dan pemberian demo pembuatan akun Instagram dan Facebook beserta cara mengelola akun tersebut.

4. Pelaksanaan pendampingan dan praktek mengoperasikan dan mengelola akun sosial media oleh oleh pelaku UMKM dalam menggunakan dan mengelola akun media sosial.

\section{HASIL DAN PEMBAHASAN}

Media sosial sebagai media pemasaran

Media sosial mempunyai pengaruh yang sangat besar di dunia bisnis. Melalui media sosial, masyarakat lebih cepat menerima informasi. Kemudahan akses dan kecepatan transfer informasi dapat dimanfaatkan oleh para pelaku UMKM untuk mempromosikan produkproduk yang dihasilkan karena jaringan internet menjangkau area yang luas dan tidak ada batasan waktu maupun wilayah. Selain itu, media sosial menjadi kanal komunikasi dengan konsumen, artinya konsumen tidak 
hanya mencari informasi suatu produk atau merek atau perusahaan melalui situs penelusuran tetapi juga melalui media sosial. Media sosial merupakan media pemasaran yang efektif (Tabroni \& Komarudin, 2021).

Menurut hasil penelitian yang dilakukan oleh Asian Development Bank Institute (Yoshino \& TaghizadehHesary, 2016), salah satu tantangan yang dihadapi pelaku UMKM saat ini adalah kemampuannya untuk bersaing dengan perusahaan yang lebih besar dalam hal akses penjualan ke pasar yang lebih luas, akses finansial dan penggunaan teknologi informasi yang belum maksimal. Pakar pemasaran Yuswohadi pun mengungkapkan bahwa jika ingin bertahan, maka pelaku UMKM harus mampu memaksimalkan manfaat perkembangan digital (Febriandirza et al., 2017).

Kondisi pandemi COVID-19 saat ini menjadikan jumlah pengguna media digital terus meningkat. Teknologi memainkan peran penting dalam menjaga kegiatan masyarakat tetap berfungsi pada saat PSBB (Komalasari, 2020). Seiring dengan adanya kebijakan jaga jarak fisik, media pemasaran digital dapat digunakan pelaku UMKM sebagai alat untuk mengembangkan dan mengoptimalkan serta mempromosikan produk yang dihasilkan. Sejalan dengan hal tersebut, Menteri Koperasi dan UKM Puspayoga menegaskan kepada para pelaku UMKM saat ini untuk benar-benar memanfaatkan internet sebagai bagian dari strategi pemasaran maupun branding produk yang dihasilkan (Sulaksono \& Zakaria, 2020).

Semakin banyaknya pesaing, menjadi pertimbangan bagi pelaku usaha untuk melakukan inovasi dalam memenangkan persaingan tersebut. Strategi komunikasi pemasaran yang tepat dapat digunakan untuk bisa meraih pangsa pasar yang dituju sehingga dapat meningkatkan penjualan (Pradiani, 2017).

Memanfaatkan internet marketing dapat memperluas jangkauan pasar, menurunkan biaya pemasaran serta meningkatkan hubungan baik dengan para pelanggan (Mokhtar, 2015). Wardhana (2015) menemukan bahwa strategi pemasaran digital berpengaruh hingga 78\% terhadap keunggulan bersaing UMK dalam memasarkan produknya. Lebih lanjut dijelaskan bahwa pemasaran secara digital memiliki beberapa keunggulan, antara lain adalah:

1. Target bisa diatur sesuai demografi, domisili, gaya hidup, dan bahkan kebiasaan.

2. Hasil cepat terlihat sehingga pemasar dapat melakukan tindakan koreksi atau perubahan apabila dirasa ada yang tidak sesuai.

3. Biaya jauh lebih murah daripada pemasaran konvensional.

4. Jangkauan lebih luas karena tidak terbatas geografis.

5. Dapat diakses kapanpun tidak terbatas waktu.

6. Hasil dapat diukur, misalnya jumlah pengunjung situs, jumlah konsumen yang melakukan pembelian online.

7. Kampanye bisa dipersonalisasi.

8. Bisa melakukan engagement atau meraih konsumen karena komunikasi terjadi secara langsung dan dilakukan secara dua arah sehingga pelaku usaha dapat membina relasi dan menumbuhkan kepercayaan konsumen.

Dengan adanya pelatihan serta pengenalan pemasaran digital ini diharapkan agar para pelaku UMKM untuk bisa lebih mengoptimalkan dan meningkatkan pengetahuan mengenai sistem pemasaran digital atau sistem pemasaran online, sebab melalui sistem pemasaran digital atau sistem pemasaran online produkproduk dari UMKM akan dapat lebih dikenal oleh masyarakat, pemesanan bisa dilakukan secara online, sehingga dapat memudahkan pembeli dan pelaku UMKM dalam bertransaksi jual beli ditengah pandemi Covid-19 saat ini. Hal tersebut sebagai solusi agar usaha yang dijalankan pelaku UMKM tidak macet. 


\section{Pelaksanaan kegiatan pengabdian}

Hasil yang dicapai dalam pengabdian masyarakat pada setiap tahapan pelaksanaan kegiatan pelatihan pemasaran digital, dijabarkan sebagai berikut:

1. Sosialisasi dan koordinasi dengan mitra. Pada tahap ini, dilakukan pemaparan mengenai gambaran pemasaran digital, pentingnya pemasaran digital, manfaat dan kelebihan menggunakan media sosial sebagai sarana pemasaran digital. Sosialisasi dilaksanakan secara interaktif, sehingga peserta dapat memahami materi yang disampaikan dengan lebih baik. Setelah pemaparan materi, dilakukan konfirmasi jadwal dan lokasi pelaksanaan kegiatan. Tim PPMT dan mitra bersepakat untuk melaksanakan pada hari Kamis, 05 November 2020.

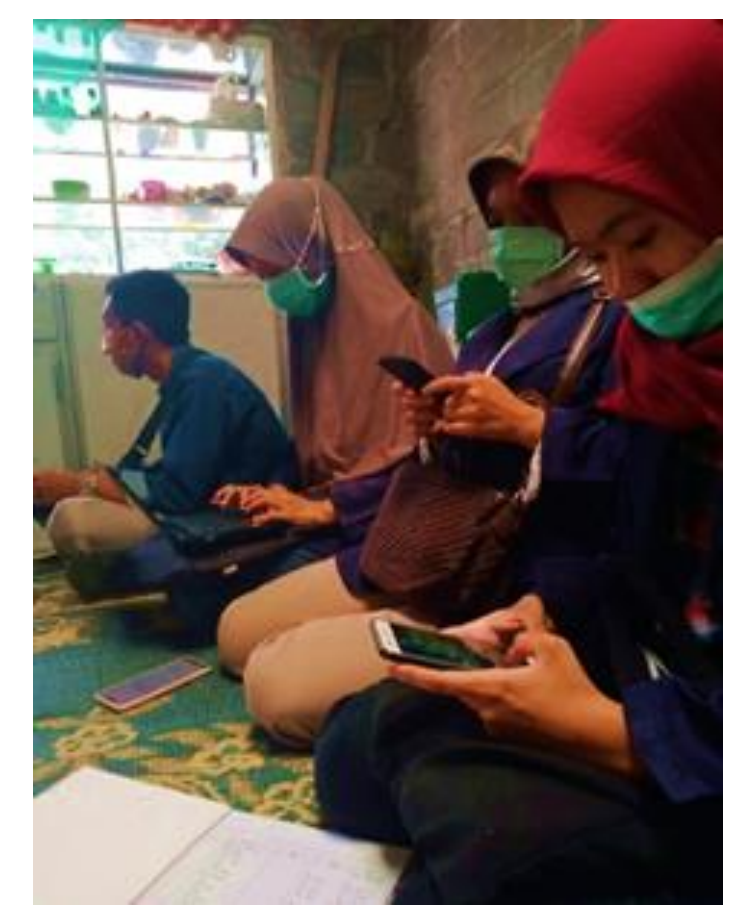

Gambar 1. Tim Pengabdian memberikan pemaparan materi terkait pemasaran digital

2. Persiapan penyuluhan dan pelatihan. Tim PPMT melakukan diskusi bersama terkait materi yang akan disampaikan pada saat kegiatan pelatihan tersebut. Pada tahap ini, juga dilakukan pembuatan akun email yang digunakan untuk membuat akun media sosial untuk masing-masing pelaku UMKM.

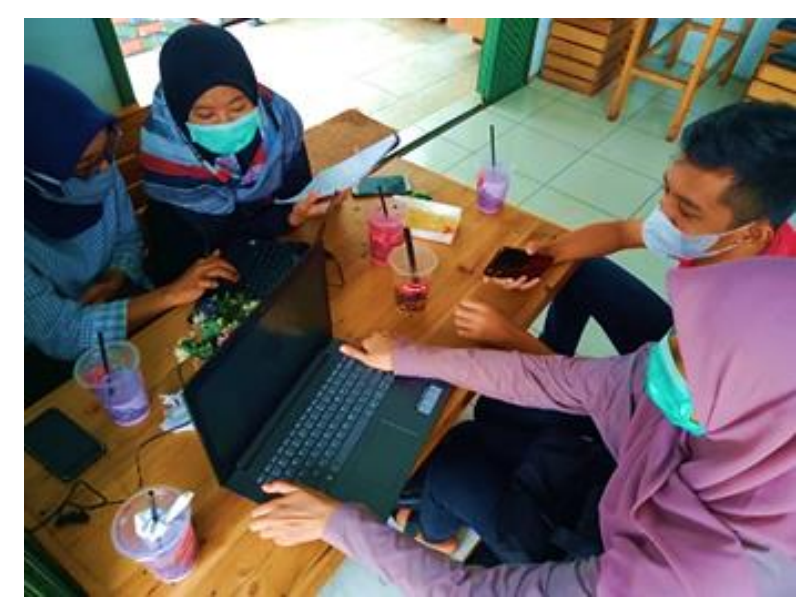

Gambar 2. Tim Pengabdian menyiapkan materi pelatihan dan akun email

3. Pelaksanaan pelatihan pemasaran digital. Pelatihan pemasaran digital dilaksanakan pada tanggal 05 November 2020. Kegiatan ini diisi dengan pemberian demo cara mengoperasikan, mengelola dan memanfaatkan akun sosial media Facebook dan Instagram.

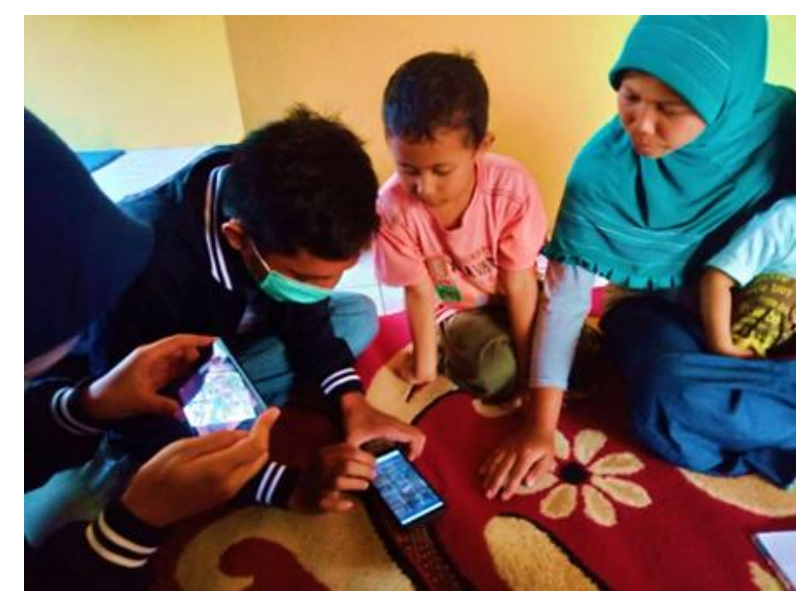

Gambar 2. Tim Pengabdian memberikan demo pengoperasian dan pengelolaan akun Facebook dan Instagram

4. Pendampingan dan praktik. Pendampingan dan praktisi dilakukan pada hari yang sama dengan demo pemasaran digital. Pada kegiatan ini, peserta pelatihan mempraktekkan secara langsung pengoperasian dan pengelolaan akun Instagram dan Facebook. Tim pelaksana mendampingi peserta pelatihan. 


\section{KESIMPULAN}

Kegiatan yang dilakukan di berberapa UMKM di Desa Srumbung, Kecamatan Srumbung, Kabupaten Magelang, Jawa Tengah ini berjalan dengan baik dan lancar. Para mitra UMKM mengikuti semua kegiatan dan tampak antusias dengan kegiatan yang dilaksanakan tim PPMT. Pelatihan ini mampu meningkatkan pengetahuan dan keterampilan peserta mengenai sistem pemasaran digital secara online. Saat ini, para pelaku UMKMyang dilatih telah memiliki akun bisnis di Instagram dan Facebook yang dimanfaatkan untuk memasarkan produknya masing-masing. Beberapa jaringan dengan pemasok dan pelanggan juga mulai terbangun. Setelah kegiatan ini berakhir, diharapkan peserta dapat melakukan pemasaran digital secara konsisten dan berkelanjutan, sehingga dapat memepermudah proses transaksi jual beli produk UMKM ditengah pandemi COVID-19 dan produkproduk yang dihasilkan dapat lebih dikenal masyarakat luas. Pada akhirnya, kegiatan yang telah dilaksanakan tim PPMT dapat memberikan manfaat jangka panjang bagi para pelaku UMKM di Desa Srumbung.

\section{UCAPAN TERIMA KASIH}

Tim PPMT mengucapkan banyak terima kasih kepada kepala Desa Srumbung beserta jajarannya yang telah memberikan fasilitas, ijin dan kepercayaan kepada kami untuk dapat melaksanakan tugas pengabdian di Desa Srumbung. Tak lupa kami ucapkan terimakasih kepada mitra yang telah berkenan untuk bekerjasama dalam pelaksanaan kegiatan pengabdian ini sehingga kegiatan dapat terlaksana dengan lancar tanpa suatu kendala.

\section{REFERENSI}

Ananda, A.D., Susilowati, D. 2017. Pengembangan Usaha Mikro Kecil Dan Menengah (UMKM)
Berbasis Industri Kreatif Di Kota Malang. Jurnal Ilmu Ekonomi. 1(1):120-142.

Bakhri, S., Futiah, V. 2020. Pendampingan dan Pengembangan Manajemen Pemasaran Produk UMKM Melalui Teknologi Digital Di Masa Pandemi Covid-19. Jurnal Loyalitas Sosial: Journal of Community Service in Humanities and Social Sciences. 2(2):59-70. http://dx.doi.org/10.32493/JLS.v2i2.p59-70

Cesaroni, F.M., Consoli, D. 2015. Are Small Businesses Really Able to Take Advantage of Social Media? The Electronic Journal of Knowledge Management. 13(4):257-268.

Febriandirza, A., Irwiensyah, F., Hasan. F.N., Indriyanti, P. 2021. Pelatihan Pemanfaatan Digital Marketing dan Manajemen Kewirausahaan bagi Pelaku UMKM dengan menggunakan Aplikasi Google My Business. Jurnal Solma. 10(1s):224-231. https://doi.org/10.22236/solma.v10i1s.6514

Hamza, L.M., Agustien, D. 2019. Pengaruh Perkembangan Usaha Mikro, Kecil, dan Menengah Terhadap Pendapatan Nasional Pada Sektor UMKM di Indonesia. Jurnal Ekonomi Pembangunan. 8(2):127-135. https://doi.org/https://doi.org/10.23960/je p.v8i2.45

Komalasari, R. 2020. Manfaat Teknologi Informasi Dan Komunikasi Di Masa Pandemi Covid 19. Tematik: Jurnal Teknologi Informasi Komunikasi. 7(1):

38-50. https://doi.org/10.38204/tematik.v7i1.369

Lembaga Pengembangan Perbankan Indonesia Bank Indonesia. 2015. Profil Bisnis Usaha Mikro, Kecil dan Menengah (UMKM). Jakarta: bank Indonesia.

Mokhtar, N.F. 2015. Internet Marketing Adoption by Small Business Enterprises in Malaysia. International Journal of Business and Social Science. 6(1):59-65.

Pakpahan, A.K. 2020. COVID-19 dan Implikasi Bagi Usaha Mikro, Kecil, dan Menengah. Jurnal Ilmiah Hubungan Internasional. 16(Edisi khusus):59-64. https://doi.org/10.26593/jihi.v0i0.3870.59-64

Pradiani, T. 2017. Pengaruh Sistem Pemasaran Pemasaran digital Terhadap Peningkatan 
Volume Penjualan Hasil Industri Rumahan. Jurnal Ilmiah Bisnis dan Ekonomi Asia. 11(2):4653. https://doi.org/10.32812/jibeka.v11i2.45

Raharja, S.J., Natari, S.U. 2021. Pengembangan Usaha UMKM Di Masa Pandemi Melalui Optimalisasi Penggunaan Dan Pengelolaan Media Digital. Kumazula: Jurnal Pengabdian Kepada Masyarakat. 4(1):108-123. https://doi.org/10.24198/kumawula.v4i1.32 361

Sulaksono, J., Zakaria, N. 2020. Peranan Digital Marketing Bagi Usaha Mikro, Kecil, Dan Menengah (UMKM) Desa Tales Kabupaten Kediri. Generation Journal. 4(1):41-48. https://doi.org/10.29407/gj.v4i1.13906

Tabroni, T., Komarudin, M. 2021. Strategi Promosi Produk Melalui Digital Marketing Bagi UMKM Terdampak Pandemi Covid'19 Berdasarkan Keputusan Konsumen. Jurnal Riset Entrepreneurship. 4(1):49-57. http://dx.doi.org/10.30587/jre.v4i1.2217

Wardhana, A. 2015. Strategi Digital Marketing Dan Implikasinya Pada Keunggulan Bersaing UKM Di Indonesia. In Prosiding forum keuangan dan bisnis Indonesia IV seminar nasional dan call for paper: Sabtu, 14 November 2015. Bandung: Universitas Pendidikan Indonesia.

Yoshino, N., Taghizadeh-Hesary, F. 2016. Major Challenges Facing Small and Medium-Sized Enterprises in Asia and Solutions for Mitigating Them. Tokyo: Asian Development Bank Institute. 